\title{
KETERAMPILAN MENULIS CERPEN DENGAN TEKNIK UBAH DIARY MAHASISWA IKIP BUDI UTOMO MALANG
}

\section{Susandi, Anita Kurnia Rachman*}

${ }^{1}$ Prodi Pendidikan Bahasa dan Sastra Indonesia, FPISH, IKIP Budi Utomo, Jl. Citandui No 46 Malang, Indonesia

*Corresponding author: anita27rachman@gmail.com

\section{INFORMASI ARTIKEL}

\section{Kata Kunci \\ Menulis \\ Fiksi \\ Cerpen \\ Ubah Diary}

Sejarah Artikel

Diterima: $10 / 9 / 2019$

Direvisi: $3 / 12 / 2019$

Diterima: 4/12/2019

Tersedia Daring: 31/12/2019

\section{ABSTRAK}

Penelitian ini bertujuan untuk mengetahui keterampilan menulis cerpen dengan teknik ubah diary pada Mata Kuliah Menulis Fiksi mahasiswa Prodi Pendidikan Bahasa dan Sastra Indonesia IKIP Budi Utomo Malang. Penelitian ini merupakan penelitian deskriptif kualitatif. Subyek penelitian mahasiswa Prodi Pendidikan Bahasa dan Sastra Indonesia Angkatan 2017 A dengan jumlah 54 orang. Langkah-langkah penelitian, yaitu (1) melakukan observasi tentang kesulitan mahasiswa dalam menulis cerpen, (2) penjelasan tentang teknik ubah diary, dan (3) penulisan cerpen dengan teknik ubah diary. Pengumpulan data dilakukan dengan (1) pengamatan langsung ke sumber data untuk mengamati proses tindakan yang dilakukan, mengumpulkan data, mencatat dan mengamati proses pembelajaran dan aktivitas mahasiswa, (2) penggunaan catatan lapangan untuk mengetahui proses pembelajaran, dan (3) menganalisis hasil menulis cerpen menggunakan rubrik penilaian yang telah disusun. Berdasarkan hasil penelitian yang dilakukan, penggunaan teknik ubah diary menghasilkan deskripsi keterampilan menulis cerpen pada mahasiswa. Deskripsi ini ditunjukkan dengan hasil tes menulis cerpen mahasiswa mencapai rata-rata $86,44 \%$ atau berkategori sangat baik. Terdapat 35 mahasiswa dengan nilai 85-100 kategori sangat baik atau 64,8\%. Sebanyak 10 mahasiswa mendapat nilai 75-84 kategori baik atau $18,52 \%$. Pada kategori cukup dengan nilai $65-$ 74 atau $14,81 \%$ sebanyak 8 mahasiswa. Pada kategori kurang dengan nilai 0-64 atau 1,86\% sebanyak 1 mahasiswa.

\section{ABSTRACT}

Keywords

Writing

Fiction

Short Stories

Change Diary
This study aims to determine the short story writing skills with diary change techniques in the Fiction Writing Subject of the Indonesian Language and Literature Education Study Program IKIP Budi Utomo Malang. This research is a qualitative descriptive study. The research subjects of the 2017 A Indonesian Language and Literature Education Study Program are 54 students. The research steps involve (1) observing the difficulties of students in writing short stories, (2) explaining the change diary technique, and (3) writing short stories with change diary techniques. Data collection is done by (1) direct observation to data sources to observe the process of action taken, collect data, record and observe the learning process and student activities, (2) using field notes to find out the learning process, and (3) analyzing the results of writing short stories using the assessment rubric that has been prepared. Based on the results of the research, the use of change diary techniques produces a description of short story writing skills to students. This description is shown by the results of the student short story writing test reaching an average of $86.44 \%$ or categorized very well. There are 35 students with grades $85-100$ in the excellent category or $64.8 \%$. A total of 10 students scored $75-84$ in good category or $18.52 \%$. In the category with moderate grades $65-74$ or $14.81 \%$ as many as 8 students. In the poor category with grade $0-64$ or $1.86 \%$ as many as 1 student. 


\section{PENDAHULUAN}

Keterampilan menulis merupakan suatu keterampilan berbahasa yang dipergunakan untuk berkomunikasi secara tidak langsung. Menulis merupakan salah satu keterampilan berbahasa yang memerlukan latihan agar dapat dikuasai dengan baik. Menulis memerlukan keterampilan seperti pilihan kata, keterkaitan paragraf, gaya bahasa dan sebagainya (Hasibuan, 2017). Kegiatan menulis merupakan suatu kegiatan yang aktif dan produktif serta memerlukan cara berpikir yang teratur yang diungkapkan dalam bahasa tulis. Sutejo (2009) menyatakan bahwa keterampilan menulis pada prinsipnya melihat adanya hubungan antara keterampilan menulis dengan keterampilan membaca melalui penulis dan pembaca. Bila penulis menuliskan sesuatu, maka orang lain atau pembaca sedikit banyak akan telibat di dalamnya. Menulis merupakan salah satu kegiatan yang menjadi komponen utama dalam pembelajaran (Aghittara, 2016). Dengan demikian, dapat dikatakan menulis merupakan salah satu cara berkomunikasi yang bersifat aktif produktif dan kompleks yang dimiliki seseorang dalam menyampaikan maksud kepada orang lain atau pembaca dengan menggunakan bahasa tulis yang baik dan benar, sehingga apa yang ditulis dan disampaikan sesuai dengan apa yang diinginkan penulis.

Menulis Fiksi menjadi mata kuliah wajib yang ditempuh oleh mahasiswa Prodi Pendidikan Bahasa dan Sastra Indonesia di IKIP Budi Utomo Malang. Mata kuliah ini menuntut mahasiswa untuk menguasai kompetensi dalam menulis prosa, khususnya cerpen. Nurmina (2016) menyatakan fiksi adalah tulisan yang dibangun berdasarkan khayalan dan umumnya bukan kenyataan. Meskipun ada beberapa fiksi yang terinspirasi dari kejadian yang benar-benar terjadi, namun ketika disajikan sebagai tulisan ada pengaruh menulis kreatif yang mengkolaborasikan antara kisah nyata dengan khalayal penulis. Oleh karena itu terciptalah sebuah karya fiksi yang bersumber dari kisah nyata tetapi diolah menjadi lebih khayal. Nurgiyantoro (2012) mengatakan bahwa tidak benar jika fiksi dianggap sebagai hasil kerja lamunan belaka, melainkan penghayatan dan perenungan secara intens, perenungan terhadap hakikat hidup dan kehidupan, perenungan yang dilakukan dengan penuh kesadaran dan tanggung jawab. Nofiyanti (2017) memperkuat pendapat Nurgiyantoro dengan mengatakan bahwa melalui karya sastra dapat diketahui eksistensi kehidupan suatu masyarakat di suatu tempat pada suatu waktu meskipun hanya pada sisi-sisi tertentu. Dengan demikian jelaslah bahwa cerpen memang jenis karya sastra yang juga memberi manfaat dan dapat mempengaruhi pembacanya seperti halnya sastra zaman dahulu.

Pembelajaran bahasa dan sastra Indonesia memiliki tujuan untuk memahami dan menerapkan segala aspek pengetahuan tentang bahasa dan sastra Indonesia, membelajarkan peserta didik tentang keterampilan berbahasa Indonesia yang benar dan baik sesuai dengan tujuan, fungsi, dan situasinya (Kristiyani, 2009). Melalui pembelajaran bahasa dan sastra Indonesia ini mahasiswa diharapkan mampu mengapresiasikan berbagai karya sastra (Mastini, Suwandi, \& Sumarwati, 2016). Keterampilan berbahasa terdiri atas empat keterampilan yaitu berbicara, membaca, menyimak, dan menulis. Keterampilan menulis merupakan keterampilan berbahasa yang paling kompleks dibandingkan dengan keterampilan mendengarkan, membaca, dan berbicara. Nurgiyantoro (2010) menjelaskan bahwa keterampilan menulis sebagai keterampilan berbahasa yang bersifat aktif produktif perlu mendapat prioritas karena 
keterampilan menulis yang baik sangat diperlukan oleh masyarakat dan menunjang karier seseorang. Salah satu keterampilan menulis yang wajib dikuasai oleh mahasiswa, yaitu menulis cerpen.

Limbong (2018) menyatakan cerpen merupakan salah satu jenis karya sastra berbentuk prosa dengan kisahan yang pendek dengan kesan tunggal dan terpusat pada satu tokoh dalam suatu situasi. Menurut Aksan (2015) cerpen adalah karya fiksi yang sering dijumpai di berbagai media massa, terutama di surat-surat kabar harian, tabloid, dan majalah-majalah. Panjangnya kira-kira 5-10 halaman kertas kuarto spasi ganda atau sekitar 1.000 sampai 2.000 kata. Jika diketik dengan komputer, kira-kira 8-12 ribu karakter. Dalam sebuah cerita pendek juga hanya dijumpai satu insiden utama yang menguasai jalan cerita, hanya ada seorang pelaku utama, dan jalan ceritanya padat. Luxemburg (dalam Wiyatmi, 2009) mengemukakan bahwa cerita pendek termasuk teks naratif yang tidak bersifat dialog dan yang isinya merupakan suatu kisah sejarah, sebuah deretan peristiwa. Bersamaan dengan kisah dan deretan peristiwa itu hadir cerita.

Cerpen memiliki unsur pembangun yang disebut unsur intrinsik. Menurut Nurgiyantoro (2010) unsur-unsur intrinsik ialah unsur-unsur yang membangun karya sastra itu sendiri. Unsur-unsur inilah yang menyebabkan karya sastra hadir yang secara faktual akan dijumpai jika orang membaca karya sastra. Unsur-unsur intrinsik yang dimaksud, yaitu (1) tema, sesuatu yang menjadi dasar cerita, tema dapat bersinonim dengan ide atau tujuan utama cerita (Nurgiyantoro, 2010). (2) Alur/plot berisi urutan kejadian, namun tiap urutan kejadian itu hanya dihubungkan secara sebab akibat, peristiwa yang satu disebabkan atau menyebabkan peristiwa yang lain. Alur meliputi alur maju, alur mundur/sorot balik/flash back, dan alur gabungan/campuran (Stanton dalam Nurgiyantoro, 2010). (3) Tokoh, tokoh adalah orang, binatang, tumbuhan, atau benda lain yang digunakan dalam cerita sebagai pelaku (Sanusi, 2013). (4) latar/setting menurut Abrams (Nurgiyantoro, 2010) latar atau setting adalah landas tumpu, menyaran pada pengertian tempat, hubungan waktu, dan lingkungan sosial tempat terjadinya peristiwa-peristiwa yang diceritakan. (5) Sudut pandang hakikatnya merupakan strategi, teknik, siasat, yang secara sengaja dipilih pengarang untuk mengemukakan gagasan dan ceritanya (Nurgiyantoro, 2010). (6) Amanat menurut Nurgiyantoro (2010) adalah pesan atau hikmah yang dapat diambil dari sebuah cerita untuk dijadikan sebagai cermin maupun panduan hidup, dan (6) gaya bahasa dalam cerpen merupakan cara pengucapan bahasa dalam prosa, atau bagaimana seseorang pengarang mengungkapkan suatu yang akan dikemukakan (Abrams dalam Nurgiyantoro, 2010).

Kendala yang dialami dalam pembelajaran sastra khususnya menulis cerpen di Prodi Pendidikan Bahasa dan Sastra Indonesia IKIP Budi Utomo, yaitu (1) pembelajaran menulis cerpen masih berorientasi pada pengetahuan tentang karya sastra, (2) sebagian pengajar tidak/belum dapat menulis cerpen, (3) pengajar tidak/belum mengetahui bagaimana strategi mengajarkan menulis cerpen, (4) pengajar belum menggunakan model pembelajaran yang dapat membantu mahasiswa menulis cerpen. Sedangkan kendala yang dialami oleh mahasiswa, yaitu; (1) mahasiswa belum mampu mengungkapkan ide, (2) mahasiswa belum mampu mengembangkam imajinasi yang dimiliki, dan (3) mahasiswa masih merasa takut untuk menulis dan menuangkan daya kreativitasnya. Berdasarkan kenyataan di lapangan, peneliti menemukan permasalahan dalam menulis cerpen pada mahasiswa. Hal ini karena mahasiswa belum memiliki teknik yang tepat untuk mengungkapkan ide dan kreativitasnya. Dosen sebagai pendidik perlu memiliki teknik yang sesuai dengan mahasiswa, sehingga mahasiswa mampu menghasilkan karya sastra khususnya cerpen yang menarik. Untuk dapat membantu mahasiswa berlatih menulis cerpen perlu adanya sarana pendukung belajar secara mandiri. Melalui sarana penunjang tersebut, mahasiswa dapat berlatih dan terus meningkatkan kemampuan menulis cerpen dalam pembelajaran di kelas maupun secara mandiri di luar jam kuliah (Amalia \& 
Doyin, 2015). Pemilihan teknik ubah diary dalam membantu mahasiswa untuk menulis cerpen diharapkan dapat mengatasi kesulitan tersebut.

Pembelajaran yang menyenangkan dan efektif penting dilakukan oleh pendidik. Hal ini masih kontras dengan keadaan di lapangan yang mengambarkan proses pendidikan yang ada di Indonesia, yang masih banyak ditemui kesenjangan tentang cara yang digunakan oleh pengajar dan mendidik dengan apa yang diinginkan oleh peserta didik. Karena saat pengajar mengajar belum tentu peserta didik juga ikut belajar (Chatib dalam Maiza, Abdurahman, \& Zulfikarni, 2018). Prayudi (2015) dalam hal ini menegaskan bahwa pembelajaran adalah suatu hal yang sengaja dirancang dan bersifat eksternal dalam mendukung proses belajar interval dari dalam diri individu. Mahasiswa bukan lagi sebagai gelas kosong yang hanya diisi air oleh pendidiknya, mahasiswa merupakan sumber daya unggul yang harus disiram, dipupuk, ditanam pada lahan dan tempat yang pas, disiangi, sehingga bibit tersebut tumbuh dan berbuah lebat, memberikan manfaat dan efek positif terhadap orang di sekitarnya. Pembelajaran yang berpusat pada mahasiswa (student centered approach) memberi kesempatan kepada mahasiswa untuk menemukan dan memperkaya pengetahuan yang mereka temukan dan mereka susun, sehingga, pendidik memiliki andil yang sangat besar untuk mengarahkan, menjembatani, dan menjadi perantara, serta pembimbing yang setia pada para peserta didiknya (Eriyanti, 2009).

Menulis diary merupakan salah satu kegiatan yang dapat dilakukan oleh anak-anak, remaja, dan orang dewasa, baik laki-laki maupun perempuan banyak yang menulis aktivitasnya di buku diary. Ciri khas dari buku diary, yaitu di dalamnya memiliki karakter: (a) ada orang/tokoh yang terlibat dalam buku harian, (b) ada penanda waktu, (c) berkaitan dengan persoalan penting (mengesankan/ menyedihkan), dan (d) ungkapan batin penulisnya, maka halhal itu sesungguhnya sudah merupakan bagian-bagian fungsional dalam sebuah cerita (Sutejo, 2009). Menulis karya sastra ada dua hal penting yang amat dominan dalam setiap kerja ke pengalaman. Kedua hal tersebut, yaitu daya imajinasi dan daya kreasi. Daya imajinasi adalah daya "membayangkan" atau "mengkhayal" segala sesuatu yang pernah menyentuh perasaan atau singgah dalam pikirannya. Sedangkan daya kreasi adalah daya "menciptakan" sesuatu yang baru, kemampuan menghadirkan sesuatu yang lain dari pada yang sudah pernah ada. Seseorang harus mempu menggabungkan imajinasi dan kreatif untuk menghasilkan suatu karya yang bagus.

Keterampilan menulis, sebagai salah satu kemahiran berbahasa yang produktif ini, mendorong seseorang untuk menyampaikan ide, pikiran, keinginan dan perasaan kepada orang lain melalui bahasa tulis. Bila dibandingkan dengan keterampilan berbahasa lainnya, sering sekali keterampilan menulis dianggap sebagai sebuah keterampilan yang paling sulit (Iskandarwassid \& Ristiani, 2010). Seperti yang disampaikan di atas, banyak alasan yang dikemukakan, antara lain karena kesulitan memulai mengekspresikan ide dalam bahasa tulis, kesulitan memilih kata-kata, kesulitan menentukan ide atau topik yang akan dituliskan, kekhawatiran salah ejaan, kekhawatiran salah dalam beretorika menulis, dan masih banyak lagi. Kesulitan dan kekhawatiran itu menyebabkan kemandegan dan akhirnya tidak menulis. Keadaan seperti itu tentu sangat tidak diharapkan karena pada hakikatnya menulis dapat dipelajari.

Permasalahan dalam penelitian ini, yaitu bagaimana keterampilan menulis cerpen mahasiswa Prodi Pendidikan Bahasa dan Sastra Indonesia IKIP Budi Utomo Malang dengan teknik ubah diary? Tujuan penelitian ini untuk mendeskripsikan keterampilan menulis cerpen mahasisiwa Prodi Pendidikan Bahasa dan Sastra Indonesia IKIP Budi Utomo Malang dengan teknik ubah diary. Manfaat dari penelitian ini dapat dijadikan landasan pengembangan pembelajaran sastra, khususnya menulis fiksi. 
Penelitian terdahulu yang relevan dengan penelitian ini, yaitu penelitian yang berjudul Peningkatan Keterampilan Menulis Cerpen Melalui Metode Pembelajaran Berbasis Pengalaman dan Media Audiovisual Pada Sekolah Menengah Pertama yang diterbitkan pada Jurnal S2 Pendidikan Bahasa Indonesia 1 yang dilakukan oleh (Mastini et al., 2016). Hasil penelitian menjelaskan bahwa dengan metode pembelajaran berbasis pengalaman dan media audiovisual dapat meningkatkan kemampuan menulis cerpen pada siswa Menengah Pertama. Penelitian yang dilakukan oleh Mashura (2016) dengan judul Peningkatan Keterampilan Menulis Cerpen dengan Strategi Copy the Master Melalui Media Audio Visual Pada Siswa Kelas IX-C SMPN 2 Toli-Toli. Penelitian yang dilakukan oleh Mashura (2016) ini menunjukkan peningkatan menulis cerpen. Peningkatan ini dilihat dari peningkatan proses dan hasil pembelajaran menulis cerpen. Penelitian ketiga dengan judul Kontribusi Minat Baca Prosa Fiksi Terhadap Keterampilan Menulis Teks Cerpen Siswa Kelas XI SMA Sungai Geringging Kabupaten Padang Pariaman yang dilakukan oleh (Maiza et al., 2018).

Ketiga penelitian tersebut memiliki kesamaan dengan penelitian ini. Kesamaan tersebut menitikberatkan pada peningkatan keterampilan menulis cerpen. Hal yang menjadi pembeda dengan penelitian sebelumnya, yaitu penelitian ini hanya mendeskripsikan hasil penggunaan teknik ubah diary dalam menulis cerpen.

\section{METODE}

Penelitian ini merupakan penelitian deskriptif yang mendeskripsikan suatu gejala, peristiwa, kejadian yang terjadi saat sekarang. Penelitian ini berlokasi di Kampus IKIP Budi Utomo Malang Jalan Citandui no 46 Malang. Pelaksanaan dilakukan pada angkatan 2017 Kelas A, yaitu 54 mahasiswa yang terdiri 31 perempuan dan 23 laki-laki. Pengampu Mata Kuliah Menulis Fiksi, yaitu Susandi, S.Pd., M.Pd dan Anita Kurnia Rachman S.Pd., M.Pd. Data dalam penelitian ini, yaitu data hasil pembelajaran yang berupa data proses dan data hasil. Instrumen dalam penelitian ini, yaitu instrumen utama dan instrumen penunjang. Instrumen utama, yaitu peneliti sendiri. Instrumen penunjang dalam penelitian ini berupa lembar penilaian. Kriteria Penilaian Keterampilan Menulis Cerpen berdasarkan Diary dapat dilihat pada Tabel 1 berikut.

Tabel 1

Kriteria Penilaian Keterampilan Menulis Cerpen

\begin{tabular}{|c|c|c|c|c|}
\hline No & $\begin{array}{c}\text { Aspek } \\
\text { Penilaian }\end{array}$ & Rincian Penilaian & $\begin{array}{c}\text { Rentang } \\
\text { Skor }\end{array}$ & Kategori \\
\hline \multirow[t]{3}{*}{1} & $\begin{array}{l}\text { Penggunaan } \\
\text { Alur atau Plot }\end{array}$ & $\begin{array}{l}\text { Permainan alur kurang menarik, kurang } \\
\text { ada tegangan dan kejutan dalam cerita } \\
\text { yang digambarkan }\end{array}$ & 1 & Kurang \\
\hline & & $\begin{array}{l}\text { Permainan alur cukup menarik, cukup ada } \\
\text { tegangan, dan kejutan pengambaran cerita } \\
\text { yang akan terjadi }\end{array}$ & 2 & Cukup \\
\hline & & $\begin{array}{l}\text { Permainan alur menarik, ada tegangan dan } \\
\text { kejutan serta pengambaran cerita yang } \\
\text { akan terjadi }\end{array}$ & 3 & Baik \\
\hline \multirow[t]{3}{*}{2} & $\begin{array}{l}\text { Pengambaran } \\
\text { tokoh dan } \\
\text { penokohan }\end{array}$ & $\begin{array}{l}\text { Pelukisan watak tokoh kurang tajam. } \\
\text { Tokoh kurang mampu membawa pembaca } \\
\text { mengalami peristiwa cerita }\end{array}$ & 1 & Kurang \\
\hline & & $\begin{array}{l}\text { Pelukisan watak tokoh cukup tajam. Tokoh } \\
\text { cukup mampu membawa pembaca } \\
\text { mengalami peristiwa cerita }\end{array}$ & 2 & Cukup \\
\hline & & $\begin{array}{l}\text { Pelukisan watak tokoh tajam. Tokoh } \\
\text { mampu membawa pembaca mengalami } \\
\text { peristiwa cerita }\end{array}$ & 3 & Baik \\
\hline
\end{tabular}


KEMBARA: Jurnal Keilmuan Bahasa, Sastra, dan Pengajarannya
Vol. 5, No. 2, Oktober, 2019, Hlm: 274-285

ISSN : 2442-7632 print | 2442-9287 online 279

\begin{tabular}{|c|c|c|c|c|}
\hline \multirow[t]{3}{*}{3} & Latar/setting & $\begin{array}{l}\text { Pemilihan latar kurang tepat dengan cerita } \\
\text { sehingga kurang mampu mengambarkan } \\
\text { suasana yang diceritakan dengan baik }\end{array}$ & 1 & Kurang \\
\hline & & $\begin{array}{l}\text { Pemilihan latar cukup tepat dengan cerita } \\
\text { sehingga cukup mampu mengambarkan } \\
\text { suasana yang diceritakan dengan baik }\end{array}$ & 2 & Cukup \\
\hline & & $\begin{array}{l}\text { Pemilihan latar tepat tepat dengan cerita } \\
\text { sehingga mampu mengambarkan suasana } \\
\text { yang diceritakan dengan baik }\end{array}$ & 3 & Baik \\
\hline \multirow[t]{3}{*}{4} & $\begin{array}{l}\text { Penggunaan } \\
\text { Gaya Bahasa }\end{array}$ & $\begin{array}{l}\text { Bahasa yang dipilih kurang tepat karena } \\
\text { tidak mengandung unsur emotif dan } \\
\text { bersifat konotatif sehingga kurang } \\
\text { mengambarkan sesuatu yang diungkapkan }\end{array}$ & 1 & Kurang \\
\hline & & $\begin{array}{l}\text { Bahasa yang dipilih kurang tepat karena } \\
\text { tidak mengandung unsur emotif dan } \\
\text { bersifat konotatif sehingga kurang } \\
\text { mengambarkan sesuatu yang diungkapkan }\end{array}$ & 2 & Cukup \\
\hline & & $\begin{array}{l}\text { Bahasa yang dipilih kurang tepat karena } \\
\text { tidak mengandung unsur emotif dan } \\
\text { bersifat konotatif sehingga kurang } \\
\text { mengambarkan sesuatu yang diungkapkan }\end{array}$ & 3 & Baik \\
\hline \multirow[t]{3}{*}{5} & $\begin{array}{l}\text { Penggunaan } \\
\text { sudut } \\
\text { pandang }\end{array}$ & $\begin{array}{l}\text { Sudut pandang yang digunakan dalam } \\
\text { menceritakan kurang tepat }\end{array}$ & 1 & Kurang \\
\hline & & $\begin{array}{l}\text { Sudut pandang yang digunakan dalam } \\
\text { menceritakan kurang tepat }\end{array}$ & 2 & Cukup \\
\hline & & $\begin{array}{l}\text { Sudut pandang yang digunakan dalam } \\
\text { menceritakan kurang tepat }\end{array}$ & 3 & Baik \\
\hline \multirow[t]{3}{*}{6} & Tema cerita & $\begin{array}{l}\text { Kurang mampu mendeskripsikan tema } \\
\text { yang dimunculkan dalam cerpen }\end{array}$ & 1 & Kurang \\
\hline & & $\begin{array}{l}\text { Kurang mampu mendeskripsikan tema } \\
\text { yang dimunculkan dalam cerpen }\end{array}$ & 2 & Cukup \\
\hline & & $\begin{array}{l}\text { Kurang mampu mendeskripsikan tema } \\
\text { yang dimunculkan dalam cerpen }\end{array}$ & 3 & Baik \\
\hline
\end{tabular}

\section{HASIL DAN PEMBAHASAN}

\section{Hasil}

Hasil penelitian ini memberikan gambaran bahwa dalam kegiatan pembelajaran menulis cerpen sangat dibutuhkan teknik yang sesuai dengan mahasiswa. Teknik ini akan membantu mahasiswa dalam menulis cerpen. Hasil penelitian ini akan dijabarkan berdasarkan aspek-aspek yang dinilai, sebagai berikut.

\section{Hasil Tes Keterampilan Menulis Cerpen Aspek Penggunaan Alur atau Plot}

Hasil data tes keterampilan menulis cerpen aspek penggunaan alur pada mahasiswa Prodi Pendidikan Bahasa dan Sastra Indonesia angkatan 2017 A dapat dilihat pada Tabel 2 berikut.

Tabel 2

Hasil Tes Keterampilan Menulis Cerpen Aspek Penggunaan Alur atau Plot

\begin{tabular}{ccccccc}
\hline No & Kategori & Skor & F & Bobot & Persen & Rata-rata Nilai \\
\hline $\mathbf{1}$ & Baik & 3 & 19 & 57 & $35,2 \%$ &
\end{tabular}




\begin{tabular}{ccccccc}
\hline $\mathbf{2}$ & Cukup & 2 & 21 & 42 & $38,9 \%$ & $=\frac{\text { Jumlah Nilai }}{\text { Fn }}$ \\
\hline $\mathbf{3}$ & Kurang & 1 & 14 & 14 & $25,9 \%$ & $=\frac{\mathbf{1 1 3}}{\mathbf{5 4}}$ \\
& & & & & $\begin{array}{c}\mathbf{2 , 0 9} \\
\text { (cukup baik) }\end{array}$ \\
\hline & Jumlah & & $\mathbf{5 4}$ & $\mathbf{1 1 3}$ & $\mathbf{1 0 0 \%}$ &
\end{tabular}

Berdasarkan Tabel 2, terdapat 19 mahasiswa mampu dengan baik dalam penggunaan alur $(35,2 \%)$. Selain itu, terdapat 21 mahasiswa yang cukup mampu dalam penggunaan alur $(38,9 \%)$. Serta terdapat 14 mahasiswa yang kurang mampu dalam penggunaan alur $(25,9 \%)$. Jadi, rata-rata menulis cerpen aspek penggunaan alur sebesar 2,09 atau berkategori cukup baik.

\section{Hasil Tes Keterampilan Menulis Cerpen Aspek Pengambaran Tokoh dan Penokohan}

Hasil data aspek pengambaran tokoh dan penokohan menulis cerpen pada mahasiswa Prodi Pendidikan Bahasa dan Sastra Indonesia angkatan 2017 A dapat dilihat pada Tabel 3 berikut.

Tabel 3

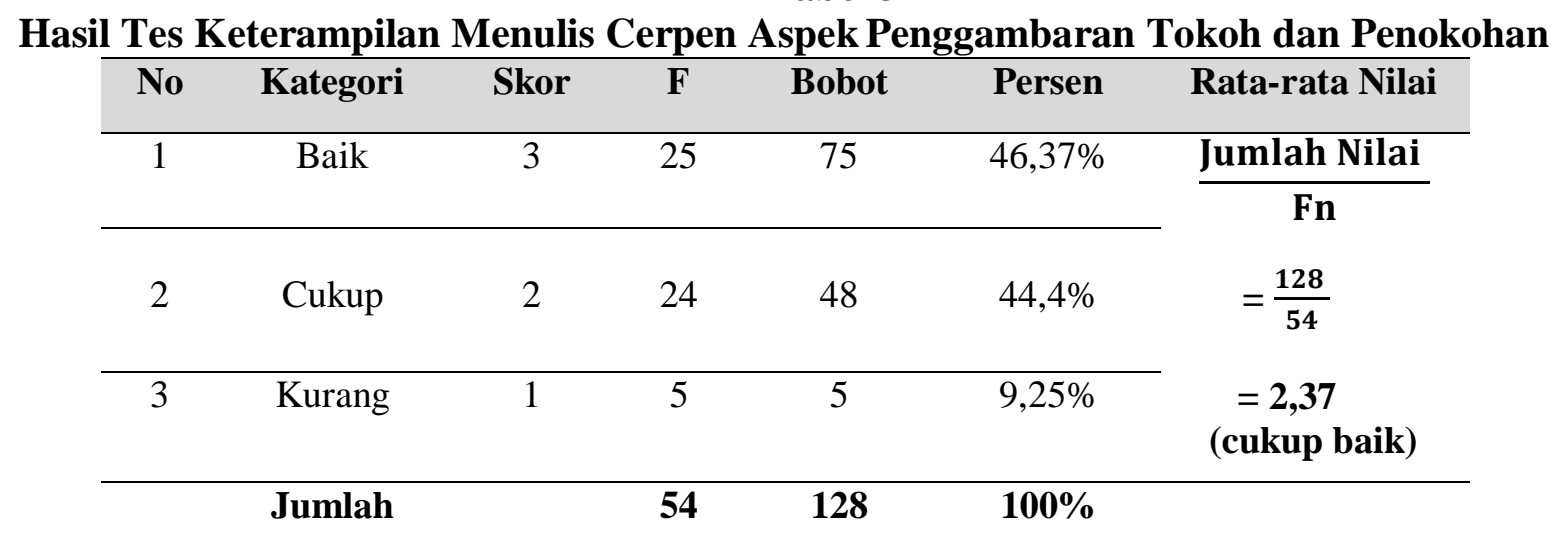

Berdasarkan Tabel 3 terdapat 25 mahasiswa mampu dengan baik menggambarkan tokoh dan penokohan $(46,37 \%)$. Terdapat 24 mahasiswa yang cukup mampu dalam penggambaran tokoh dan penokohan $(44,4 \%)$. Terdapat 5 mahasiswa yang kurang mampu dalam penggambaran tokoh dan penokohan $(9,25 \%)$. Jadi, rata-rata mahasiswa dari hasil menulis cerpen aspek penggambaran tokoh atau penokohan sebesar 2,37 atau berkategori cukup baik.

\section{Hasil Tes Keterampilan Menulis Cerpen Aspek Pendeskripsian Latar}

Hasil data aspek pendeskripsian latar pada mahasiswa Prodi Pendidikan Bahasa dan Sastra Indonesia angkatan 2017 A dapat dilihat pada Tabel 4 berikut. 
KEMBARA: Jurnal Keilmuan Bahasa,

Sastra, dan Pengajarannya
Vol. 5, No. 2, Oktober, 2019, Hlm: 274-285

ISSN : 2442-7632 print | 2442-9287 online

281

Tabel 4

Hasil Tes Keterampilan Menulis Cerpen Aspek Pendeskripsian Latar

\begin{tabular}{ccccccc}
\hline No & Kategori & Skor & F & Bobot & Persen & Rata-rata Nilai \\
\hline 1 & Baik & 3 & 25 & 75 & $46,3 \%$ & $\frac{\text { Jumlah Nilai }}{\text { Fn }}$ \\
\cline { 1 - 1 } 2 & Cukup & 2 & 20 & 40 & $37,04 \%$ & $\begin{array}{c}=\frac{\mathbf{1 2 4}}{\mathbf{5 4}} \\
=\mathbf{2 , 3} \\
\text { (cukup baik) }\end{array}$ \\
\hline & Kurang & 1 & 9 & 9 & $16,7 \%$ & \\
\hline & Jumlah & $\mathbf{5 9}$ & $\mathbf{1 2 4}$ & $\mathbf{1 0 0 \%}$ & \\
\hline
\end{tabular}

Berdasarkan Tabel 4 terdapat 25 mahasiswa yang mampu dengan baik dalam mendeskripsikan latar (46,3\%). Terdapat 20 mahasiswa yang cukup mampu dalam mendeskripsikan latar $(37,04 \%)$. Terdapat 9 mahasiswa yang kurang mampu dalam mendeskripsikan latar $(16,7 \%)$. Jadi, rata-rata mahasiswa dari hasil menulis cerpen aspek mendeskripsikan latar sebesar 2,3 atau berkategori cukup baik.

\section{Hasil Tes Keterampilan Menulis Cerpen Aspek Penggunaan Gaya Bahasa}

Hasil data aspek penggunaan gaya bahasa pada mahasiswa Prodi Pendidikan Bahasa dan Sastra Indonesia angkatan 2017 A dapat dilihat pada Tabel 5 berikut.

Tabel 5

Hasil Tes Keterampilan Menulis Cerpen Aspek Penggunaan Gaya Bahasa

\begin{tabular}{ccccccc}
\hline No & Kategori & Skor & F & Bobot & Persen & Rata-rata Nilai \\
\hline 1 & Baik & 3 & 20 & 60 & $37,04 \%$ & $\frac{\text { Jumlah Nilai }}{\text { Fn }}$ \\
\cline { 1 - 1 } 2 & Cukup & 2 & 15 & 30 & $27,8 \%$ & $\begin{array}{c}\mathbf{1 0 9} \\
\mathbf{5 4} \\
=\mathbf{2 . 0 2} \\
\text { (cukup baik) }\end{array}$ \\
\hline & Kurang & 1 & 19 & 19 & $35,2 \%$ & \\
\hline & Jumlah & & $\mathbf{5 4}$ & $\mathbf{1 0 9}$ & $\mathbf{1 0 0 \%}$ &
\end{tabular}

Berdasarkan Tabel 5 terdapat 20 mahasiswa mampu dengan baik dalam penggunaan gaya bahasa $(37,05 \%)$. Terdapat 15 mahasiswa yang cukup mampu dalam penggunaan gaya bahasa $(27,8 \%)$. Terdapat 19 siswa yang kurang mampu dalam penggunaan gaya bahasa $(35,2 \%)$. Jadi, rata-rata mahasiswa dari hasil menulis cerpen aspek penggunaan gaya bahasa sebesar 2,02 atau berkategori cukup baik. 


\section{Hasil Tes Keterampilan Menulis Cerpen Aspek Penggunaan Sudut Pandang}

Hasil data aspek penggunaan sudut pandang pada mahasiswa Prodi Pendidikan Bahasa dan Sastra Indonesia angkatan 2017 A dapat dilihat pada Tabel 6 berikut.

Tabel 6

Hasil Tes Keterampilan Menulis Cerpen Aspek Penggunaan Sudut Pandang

\begin{tabular}{|c|c|c|c|c|c|c|}
\hline No & Kategori & Skor & $\mathrm{F}$ & Bobot & Persen & Rata-rata Nilai \\
\hline \multirow[t]{2}{*}{1} & Baik & 3 & 28 & 84 & $51,85 \%$ & Jumlah Nilai \\
\hline & & & & & & Fn \\
\hline 2 & Cukup & 2 & 21 & 42 & $38,9 \%$ & $=\frac{131}{54}$ \\
\hline \multirow[t]{2}{*}{3} & Kurang & 1 & 5 & 5 & $9,26 \%$ & $\begin{array}{c}=2,42 \\
\text { (cukup baik) }\end{array}$ \\
\hline & Jumlah & & 54 & 131 & $100 \%$ & \\
\hline
\end{tabular}

Berdasarkan Tabel 6 terdapat 28 mahasiswa mampu dengan baik dalam penggunaan sudut pandang $(51,85 \%)$. Terdapat 21 siswa yang cukup mampu dalam penggunaan sudut pandang $(38,9 \%)$. Terdapat 5 mahasiswa yang kurang mampu dalam penggunaan sudut pandang $(9,26 \%)$. Jadi, rata-rata mahasiswa dari hasil menulis cerpen aspek penggunaan sudut pandang sebesar 2,42 atau berkategori cukup baik.

\section{Hasil Tes Keterampilan Menulis Cerpen Aspek Penggunaan Kesesuaian Tema dan Ceritanya}

Hasil data aspek kesesuaian tema dan ceritanya Hasil data aspek penggunaan sudut pandang pada mahasiswa Prodi Pendidikan Bahasa dan Sastra Indonesia angkatan 2017 A dapat dilihat pada Tabel 7 berikut.

Tabel 7

Hasil Tes Keterampilan Menulis Cerpen Aspek Kesesuaian Tema dan Ceritanya

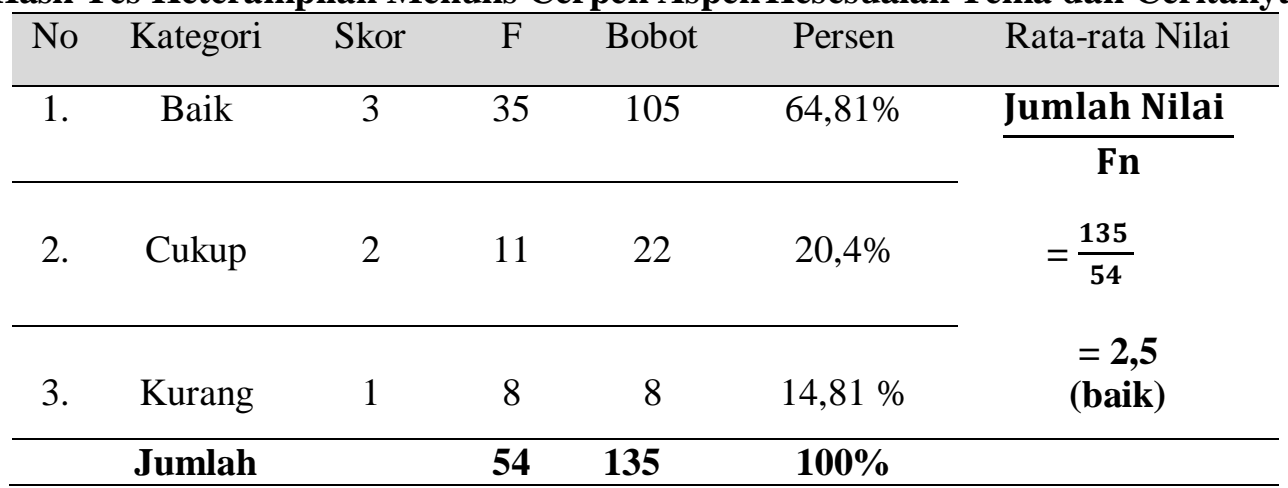

Berdasarkan Tabel 7 terdapat 35 mahasiswa yang mampu dengan baik dalam membuat kesesuaian tema dan ceritanya $(64,81 \%)$. Terdapat 11 mahasiswa yang cukup mampu dalam membuat kesesuaian tema dan ceritanya $(20,4 \%)$. Terdapat 8 mahasiswa yang kurang mampu membuat kesesuaian tema dan ceritanya $(14,81 \%)$. Jadi, rata-rata mahasiswa dari hasil menulis cerpen aspek kesesuaian tema dan ceritanya sebesar 2,5=3 atau berkategori baik. 


\section{Hasil Tes}

Hasil tes menulis cerpen setelah diberlakukannya tindakan pembelajaran dengan menggukan teknik ubah diary. Hasil menulis cerpen yang dihasilkan oleh mahasiswa dapat dilihat pada Tabel 8 berikut.

Tabel 8

Hasil Tes Menulis Cerpen dengan Teknik Ubah Diary

\begin{tabular}{|c|c|c|c|c|c|c|}
\hline No & Kategori & Nilai & $\mathbf{F}$ & Bobot & Persen & Rata-rata Nilai \\
\hline 1. & Sangat Baik & $85-100$ & 35 & 3220 & $64,8 \%$ & \multirow{4}{*}{$\begin{array}{c}\frac{\text { Jumlah Nilai }}{\text { Fn }} \\
=\frac{4640}{54} \\
=86 \\
\text { (sangat baik) }\end{array}$} \\
\hline 2. & Baik & $75-84$ & 10 & 800 & $18,52 \%$ & \\
\hline 3. & Cukup & $65-74$ & 8 & 560 & $14,81 \%$ & \\
\hline \multirow[t]{2}{*}{4.} & Kurang & $0-64$ & 1 & 60 & $1,86 \%$ & \\
\hline & Jumlah & & 54 & 4640 & $100 \%$ & \\
\hline
\end{tabular}

Data Tabel 8 menunjukan hasil tes keterampilan menulis cerpen mahasiswa menggunakan teknik ubah diary mencapai rata-rata 64,8\% atau berkategori sangat baik dengan jumlah 35 mahasiswa dengan nilai 85-100. Sebanyak 10 mahasiswa mendapat nilai 75-84 kategori baik atau $18,52 \%$. Pada kategori cukup dengan nilai $65-74$ atau $14,81 \%$ sebanyak 8 mahasiswa. Pada kategori kurang dengan nilai 0-64 atau 1,86\% sebanyak 1 mahasiswa.

\section{PEMBAHASAN}

Hasil penelitian menunjukkan bahwa penggunaan teknik diary pada penulisan cerpen memberikan hasil yang postif. Hal ini dapat dilihat dari tiap aspek penilaian yang digunakan untuk mengukur kemampuan mahasiswa dalam menulis cerpen. Masing-masing aspek penilaian memberikan dampak pada hasil penulisan cerpen oleh mahasiswa. Penilaian ini berbentuk rambu-rambu penilaian. Penilaian aspek ini sesuai dengan proses evaluasi menulis sastra khususnya cerpen. Alat evaluasi hasil pembelajaran menulis cerpen dengan menggunakan teknik ubah diary merujuk pada hasil belajar yang dilakukan mahasiswa. Alat evaluasi yang digunakan, yaitu berupa rambu-rambu penilaian.

Pentingnya evaluasi dalam pembelajaran, mengakibatkan seorang pengajar harus memiliki persiapan dan kompetensi yang baik, baik dari segi perencanaan pembelajaran, dan kemampuan pengajar mengembangkan proses pembelajaran serta penguasaannya terhadap bahan ajar, dan juga tidak cukup dengan kemampuan pengajar dalam menguasai kelas, tanpa diimbangi dengan kemampuan melakukan evaluasi terhadap perencanaan kompetensi siswa yang sangat menentukan dalam konteks perencanaan berikutnya, atau kebijakan perlakuan terhadap siswa terkait dengan konsep belajar tuntas (Purwanto, 2009).

Evaluasi pembelajaran menulis cerpen menyangkut dua sasaran, yaitu evaluasi proses dan evaluasi hasil pembelajaran. Proses pembelajaran merupakan kegiatan yang dilaksanakan untuk mencapai tujuan yang diharapkan, sedangkan hasil belajar merupakan tingkah laku yang dapat diubah dari proses pembelajaran. Evaluasi proses bertujuan untuk mengetahui aktivitas dan partisipasi peserta didik. Penilaian proses pembelajaran dilakukan selama pembelajaran berlangsung pada setiap pertemuan dan beberapa pertemuan berikutnya sampai selesai dipelajarinya satu kompetensi. Penilaian hasil pembelajaran dilakukan minimal setelah satu kompetensi dasar dipelajari (Ginting \& Permana, 2018). 
Temuan penelitian juga menunjukkan bahwa teknik ubah diary menjadi salah satu alternatif bagi dosen untuk mengajarkan keterampilan menulis cerpen kepada mahasiswa. Bagi mahasiswa, diary merupakan hal yang sudah tidak asing lagi bagi mahasiswa. Untuk inilah, dalam banyak pengalaman buku harian ini banyak dimanfaatkan dalam mendorong inspirasi kepenulisan seseorang. Danarto misalnya, pernah mengisahkan pentingnya buku harian dalam pelahiran karya-karyanya (Sutejo, 2009).

\section{SIMPULAN}

Berdasarkan hasil penelitian, dapat disimpulkan dua hal, yaitu (1) kegiatan menulis cerpen pada mahasiswa menggunakan teknik ubah diary sangat membantu mahasiswa dalam mengungkapkan ide dan gagasan untuk menulis sebuah cerpen. Hal ini ditunjukkan dari hasil tes keterampilan menulis cerpen mahasiswa menggunakan teknik ubah diary mencapai ratarata $86,44 \%$ atau berkategori sangat baik. Terdapat 35 mahasiswa dengan nilai 85-100 kategori sangat baik atau 64,8\%. Sebanyak 10 mahasiswa mendapat nilai 75-84 kategori baik atau $18,52 \%$. Pada kategori cukup dengan nilai $65-74$ atau 14,81\% sebanyak 8 mahasiswa. Pada kategori kurang dengan nilai 0-64 atau 1,86\% sebanyak 1 mahasiswa. (2) Penggunaan berbagai teknik dan media yang ada di sekitar mahasiswa untuk meningkatkan keterampilan menulis sangat diperlukan. Hal ini supaya mahasiswa lebih terampil dalam mengembangkan ide, gagasan, dan berpikir kreatif dalam menghasilkan tulisan khususnya dalam menuis prosa fiksi. Dukungan dan motivasi dosen kepada mahaiswa supaya mahasiswa lebih memiliki tingkat kepercayaan diri dalam menunjukkan hasil karyanya.

\section{DAFTAR PUSTAKA}

Aghittara, A. O. (2016). Peningkatan Keterampilan Menulis Cerita Fiksi Melalui Metode Eksplorasi Membaca Siswa Kelas IV. BASIC EDUCATION, 5(30), 2-831-832.837.

Aksan, H. (2015). Proses Kreatif Menulis Puisi. Bandung: Nuansa.

Amalia, A., \& Doyin, M. (2015). Pengembangan Buku Panduan Menyusun Teks Cerpen dengan Menggunakan Teknik Urai Unsur Intrinsik Bagi Siswa Kelas VII Sekolah Menengah Pertama (SMP). Jurnal Pendidikan Bahasa dan Sastra Indonesia, 4(2), 1-6.

Eriyanti, R. W. (2009). Peningkatan Kemampuan Mengembangkan Gagasan dalam Menulis Ilmiah dengan Pendekatan Kontekstual bagi Mahasiswa Jurusan Pendidikan Bahasa dan Sastra Indonesia. LITERA, 8(1), 57-66.

Ginting, E., \& Permana, Y. (2018). PEDAGOGI: Penilaian Evaluasi Proses dan Hasil Belajar. Jakarta: Direktorat Jenderal Guru dan Tenaga Kependidikan Kementerian Pendidikan dan Kebudayaan

Hasibuan, S. (2017). Meningkatkan Kemampuan Menulis Karangan Deskripsi dengan Metode Latihan Terbimbing Menggunakan Gambar di SMAN 4 Pekanbaru. GERAM, 5(2), 16.

Iskandarwassid, \& Ristiani, I. (2010). Peningkatan Kemampuan Menulis Narasi Melalui Model Pembelajaran Teknik Visual-Auditif-Taktil (Penelitian pada siswa Sekolah Dasar di Kabupaten Cianjur). Jurnal Penelitian Pendidikan, 11(1), 1-10.

Kristiyani, A. (2009). Penerapan Pendekatan Kontekstual untuk Meningkatkan Keterampilan Menulis Laporan Siswa Kelas VIII SMP. LITERA, 8(1), 1-10.

Limbong, J. L. (2018). Kemampuan Menentukan Unsur Intrinsik Cerpen Melalui Model Pembelajaran Inkuiri Siswa Kelas VIII SMP Negeri 10 Kota Palopo Jurnal Onoma: Pendidikan, Bahasa, dan Sastra, 2(1), 12-26.

Maiza, R. A., Abdurahman, A., \& Zulfikarni, Z. (2018). Kontribusi Minat Baca Prosa Fiksi terhadap Keterampilan Menulis Teks Cerpen Siswa Kelas XI SMA Sungai Geringging Kabupaten Padang Pariaman Pendidikan Bahasa dan Sastra Indonesia, 7(3), 295-301. 
Mashura, M. (2016). Peningkatan Keterampilan Menulis Cerpen dengan Strategi Copy the Master Melalui Media Audio Visual pada Siswa Kelas IX-C SMPN 2 Toli-Toli. Jurnal Kreatif Tadulako, 4(11), 237-248.

Mastini, M., Suwandi, S., \& Sumarwati, S. (2016). Peningkatan Keterampilan Menulis Cerpen Melalui Metode Pembelajaran Berbasis Pengalaman dan Media Audiovisual pada Sekolah Menegah Pertama Jurnal S2 Pendidikan Bahasa Indonesia, 1(1), 22-34.

Nofiyanti, N. (2017). Pendidikan Karakter dalam Cerpen "Robohnya Surau Kami" Karya AA Navis Semantik, 3(2), 114-128.

Nurgiyantoro, B. (2010). Teori Pengkajian Fiksi. Yogyakarta: Gadjah Mada University Press. Nurgiyantoro, B. (2012). Teori Pengkajian Fiksi. Yogyakarta: Gajah Mada University Press. Nurmina, N. (2016). Menulis Fiksi dengan Model Pembelajaran Efektif untuk Siswa Sekolah Dasar Kelas Tinggi. Jurnal Pendidikan Almuslim, 4(1), 16-20.

Prayudi, P. (2015). Penerapan Model Group Investigation Berbasis Kontekstual pada Pembelajaran Fisika di Sekolah Menengah Atas. JINoP (Jurnal Inovasi Pembelajaran), $1(1), 69-76$.

Purwanto, M. N. (2009). Prinsip-Prinsip Evaluasi Pengajaran. Bandung: Remaja Rosda Karya.

Sanusi, A. E. (2013). Penilaian Pengajaran Bahasa dan Sastra. Bandar Lampung: Universitas Lampung.

Sutejo. (2009). Teknik Kreativitas Pembelajaran. Surabaya: Lentera Cendikia.

Wiyatmi. (2009). Pengantar Kajian Sastra. Yogyakarta: Pustaka Book Publisher. 